\title{
Measurement of the Aging of Rubber Vulcanizates
}

\author{
J. Mandel, F. L. Roth, M. N. Steel, and R. D. Stiehler
}

(June 19, 1959)

\begin{abstract}
A study of aging data in the literature and of measurements made at the National Bureau of Standards indicates that ultimate elongation is the best of the tensile properties for characterizing the deterioration of rubber vulcanizates during storage at various temperatures. Ultimate elongation (strain at failure) decreases during aging for all types of rubber vulcanizates; whereas tensile strength and modulus may increase, decrease, or remain essentially unchanged.

This study includes measurements of ultimate elongation of a nitrile rubber vulcanizate after various periods of storage at temperatures of $23^{\circ}, 34^{\circ}, 45^{\circ}, 57^{\circ}, 70^{\circ}, 85^{\circ}$, and $100^{\circ} \mathrm{C}$. It also includes a study of the published data on ultimate elongation obtained in an interlaboratory test conducted by Subcommittee 15 of ASTM Committee D-11, involving vulcanizates of five different rubbers stored at $25^{\circ}, 70^{\circ}, 100^{\circ}$, and $121^{\circ} \mathrm{C}$.

The change in ultimate elongation over prolonged periods of storage cannot be expressed by a simple mathematical equation. However, during most of the useful storage life of a rubber vulcanizate, the elongation decreases approximately linearly with the square root of time. The data indicate that for some vulcanizates an estimate of storage life at room temperature can be made from measurements of ultimate elongation at two or more elevated temperatures.
\end{abstract}

\section{Introduction}

The aging of rubber vulcanizates has received the attention of many workers and has been the subject of two symposia [1, 2] ${ }^{1}$ and a monograph [3]. It has been generally assessed from changes in tensile properties resulting from conditioning at elevated temperatures for specified periods of time. For historical reasons, greater attention has been given to changes in tensile strength than to changes in the other tensile properties. This emphasis probably resulted from the usefulness of this property in predicting the aging behavior of natural rubber vulcanizates.

A study of the results reported in the literature by Schoch and Juve [4], Buist [3], and others reveals that tensile strength is of little or no value in predicting the aging of synthetic rubber vulcanizates. Upon aging or conditioning at elevated temperatures the tensile strength of these vulcanizates may remain essentially unchanged or even increase. Similarly, the change in modulus or stiffness is not a consistent indicator of the aging process. Synthetic rubber vulcanizates generally become harder on aging; whereas natural rubber vulcanizates may become either harder or softer depending on the conditions and the particular vulcanizate. On the other hand, the ultimate elongation or strain at failure of both natural and synthetic rubber vulcanizates consistently decreases on aging. It is surprising that this property has not received more attention since it is unique for distinguishing elastomers from other materials and is the most valuable of the tensile properties for determining the utility of a rubber compound for a particular application. Further, this property appears to change upon aging in some semblance of an orderly manner. This paper presents a study of this

\footnotetext{
Figures in brackets indicate the literature references at the end of this paper.
}

change. The study is restricted to an aging test conducted on a nitrile-butadiene rubber (NBR) vulcanizate at NBS and to the results for the various rubber compounds reported by Schoch and Juve [4]. In all tests, the ultimate elongation is measured on dumbbell-shaped specimens having a cross section in the constricted part approximately 0.25 by 0.08 in. and bench marks 1 -in. apart (Die C, ASTM Designation D412-51T [5]).

\section{Experimental Procedures}

Vulcanizates of NBR were prepared in accordance with the procedure for formulation $1 \mathrm{E}$ in ASTM Designation D15-57T[5]. NBS standard materials for rubber compounding were used except for the rubber which was a sample of Hycar 1042. For each temperature of aging, three mixes were prepared and blended. From the blended batch, 16 standard sheets (approximately $15 \times 15 \times 0.2 \mathrm{~cm}$ ) were vulcanized for $40 \mathrm{~min}$ at $150^{\circ} \mathrm{C}$. Six specimens were cut from each sheet using Die C, ASTM Designation D412-51T[5]. One specimen from each sheet was tested the day after vulcanization. Another specimen from each sheet was tested after each of five prescribed periods of aging at a particular temperature. The position of the specimen in the sheet was noted. The specimens selected for any one period of aging were approximately equally divided among outside, center, and intermediate positions in the 16 sheets. Five periods of aging at each of seven temperatures were used in this study, as shown in table 1.

\section{Results}

The mean value for each set of 16 specimens comprising the test under each prescribed condition of time and temperature is given in table 2 . In order 
TABLE 1. Temperatures and periods of oging

\begin{tabular}{|c|c|c|c|c|c|c|}
\hline \multirow{2}{*}{$\begin{array}{c}\text { Aging temp } \\
\circ \mathrm{C}\end{array}$} & \multicolumn{6}{|c|}{ Period of aging (in days) } \\
\hline & $\mathrm{A}$ & $\mathrm{B}$ & $\mathrm{C}$ & $\mathrm{D}$ & $\mathrm{E}$ & $\mathrm{F}$ \\
\hline $\begin{array}{l}23 \\
34 \\
45 \\
57\end{array}$ & $\begin{array}{l}0 \\
0 \\
0 \\
0\end{array}$ & $\begin{array}{r}100 \\
30 \\
10 \\
4.9\end{array}$ & $\begin{array}{c}377 \\
120 \\
41 \\
12.9\end{array}$ & $\begin{array}{c}(\mathrm{a}) \\
270 \\
90 \\
51\end{array}$ & $\begin{array}{r}(\mathrm{a}) \\
(\mathrm{a}) \\
160 \\
79\end{array}$ & $\begin{array}{r}(\mathrm{a}) \\
(\mathrm{a}) \\
359 \\
113\end{array}$ \\
\hline $\begin{array}{l}70 \text { (a) } \\
70 \text { (b) } \\
85 \\
100 \text { (a) } \\
100 \text { (b) }\end{array}$ & $\begin{array}{l}0 \\
0 \\
0 \\
0 \\
0\end{array}$ & $\begin{array}{l}1 \\
5 \\
1.21 \\
0.110 \\
.67\end{array}$ & \begin{tabular}{l}
\multicolumn{4}{c}{} \\
20 \\
2.71 \\
0.375 \\
2.67
\end{tabular} & $\begin{array}{l}9 \\
46 \\
4.83 \\
0.90 \\
6\end{array}$ & $\begin{array}{l}16 \\
81 \\
12 \\
1.64 \\
10\end{array}$ & $\begin{array}{c}25 \\
148 \\
15.7 \\
2.67 \\
16.7\end{array}$ \\
\hline
\end{tabular}

a Test still in progress.

to have a basis for studying these results, it is necessary to know the magnitude of the error. Table 3 gives the analysis of variance for the nine groups of unaged specimens. It is inferred from this analysis that the standard deviation of a specimen taken at random from. one of the 16 sheets comprising a batch is 30 percent elongation or a coefficient of variation of 4.8 percent. Perhaps a more pertinent measure of error is the one derived from the mean square for the interaction between sheets and aging times. Table 4 gives this information for each of the nine batches. The average coefficient of variation of 5.7 percent is somewhat larger than the 4.8 percent noted above since it includes variability introduced by aging. However, it is not larger than the 5.9 percent coefficient of variation for a specimen taken at random from any batch. Thus, the design of test makes the experiment more efficient than a complete random. selection of specimens from all batches. Since 16 specimens are used for each aging condition, the overall coefficient of variation is about 1.4 percent.

It is seen in table 1 that two batches were tested at both $70^{\circ}$ and $100^{\circ} \mathrm{C}$. The purpose of the second batch is to obtain data under conditions of more extensive aging. In the case of the second batch tested at $100^{\circ} \mathrm{C}$, the ultimate elongation is reduced much more than that for any of the other batches, being less than 100 percent after the longest period of aging.

Attempts to express the data in table 2 by the standard kinetic equations for a first or a second order reaction were not successful. Other mathe-

TABLE 2. Ultimate elongations of NBR vulcanizate after prescribed conditions of aging

\begin{tabular}{|c|c|c|c|c|c|c|}
\hline \multirow{2}{*}{ Aging temp. } & \multicolumn{6}{|c|}{ Elongation after period of aging a } \\
\hline & A & $\mathrm{B}$ & $\mathrm{C}$ & $\mathrm{D}$ & $\mathrm{E}$ & $\mathrm{F}$ \\
\hline \multirow[t]{3}{*}{${ }^{\circ} \mathrm{C}$} & \multirow{3}{*}{$\begin{array}{c}\% \\
652 \\
623 \\
609 \\
614\end{array}$} & \multirow{3}{*}{$\begin{array}{c}\% \\
604 \\
580 \\
576 \\
563\end{array}$} & \multirow{3}{*}{$\begin{array}{c}\% \\
528 \\
534 \\
532 \\
513\end{array}$} & $\%$ & $\%$ & $\%$ \\
\hline & & & & 475 & & \\
\hline & & & & $\begin{array}{l}494 \\
436\end{array}$ & $\begin{array}{l}465 \\
402\end{array}$ & $\begin{array}{l}394 \\
404\end{array}$ \\
\hline 70 (a) & 596 & 593 & 548 & 527 & 480 & 433 \\
\hline & 626 & 496 & 420 & 359 & 305 & 251 \\
\hline & 609 & 532 & 461 & 419 & 342 & 321 \\
\hline $100(\mathrm{a}$ & 656 & 581 & 548 & 461 & 418 & 371 \\
\hline 100 & 654 & 489 & 353 & 249 & 152 & 67 \\
\hline
\end{tabular}

a See table 1 for duration of period.
TABLE 3. Analysis of variance-unaged specimens

\begin{tabular}{|c|c|c|c|}
\hline Source of variation & $\begin{array}{l}\text { Degrees of } \\
\text { freedom }\end{array}$ & Mean square & $\begin{array}{l}\text { Component } \\
\text { of variance }\end{array}$ \\
\hline $\begin{array}{l}\text { Between batches } \\
\text { Within batches.-- }\end{array}$ & $\begin{array}{r}8 \\
135\end{array}$ & $\begin{array}{r}7947 \\
921\end{array}$ & $\begin{array}{l}439 \\
921\end{array}$ \\
\hline
\end{tabular}

TABLE 4. Estimation of variability derived from interaction of sheet and aging time

\begin{tabular}{|c|c|c|c|}
\hline Aging temp. & Mean elong. & Mean square & $\begin{array}{l}\text { Coefficient } \\
\text { of variation }\end{array}$ \\
\hline $\begin{array}{l}{ }^{\circ} \mathrm{C} \\
23 \\
34 \\
45 \\
57\end{array}$ & $\begin{array}{l}\% \\
595 \\
553 \\
512 \\
489\end{array}$ & $\begin{array}{r}1132 \\
762 \\
667 \\
821\end{array}$ & $\begin{array}{l}\% \\
5.6 \\
5.0 \\
5.0 \\
5.9\end{array}$ \\
\hline $\begin{array}{l}70(\mathrm{a}) \\
70(\mathrm{~b}) \\
85 \\
100(\mathrm{a}) \\
100(\mathrm{~b})\end{array}$ & $\begin{array}{l}530 \\
409 \\
447 \\
506 \\
327\end{array}$ & $\begin{array}{l}824 \\
899 \\
734 \\
604 \\
494\end{array}$ & $\begin{array}{l}5.4 \\
7.3 \\
6.1 \\
4.9 \\
6.8\end{array}$ \\
\hline & & $771 \mathrm{avg}$ & $5.8 \mathrm{avg}$ \\
\hline
\end{tabular}

matical expressions of the form

$$
y=A e^{-B t^{n}} \text { and } y=A e^{-B t}+C e^{-D t}
$$

were tried. The latter expression described the data well for long periods of aging, but it did not satisfactorily account for the early part of the curve. Further, this equation was difficult to apply. Therefore, the data were empirically fitted to a power series of the form:

$$
y=a+b x+c x^{2}+d x^{3}+\ldots .
$$

It was observed that when $x=\sqrt{t}$ and $y$ is the ultimate elongation, the first two terms in this series satisfactorily expressed the data in table 2 except for the last three points of the second batch at $100^{\circ}$ $\mathrm{C}$ where less than half of the original elongation remained. Accordingly, a study was made of the general applicability of the following simplified equation for expressing the change in elongation upon aging:

$$
E=E_{0}-k \sqrt{t}
$$

where $E=$ ultimate elongation after aging for time $t$, and $E_{\mathrm{o}}$ and $k$ are parameters of the vulcanizate.

Table 5 gives the values of the parameters $E_{0}$ and $k$ calculated by the method of least squares from the data in table 2. This table also gives the standard deviations and coefficients of variation of the points from the linear regression. These coefficients of variation include the inherent error of 1.4 percent, any variability in temperature during the prolonged periods of aging, and deviations of the true aging curve from eq (2). The coefficients of variation in table 4 indicate that eq (2) is quite close to the true aging curve with the possible exception of batch (b) at $70^{\circ} \mathrm{C}$. The ultimate elongation of the unaged specimens for this batch does not conform with the rest of the data for this batch at later times. 
Figure 1 shows the agreement between the experimental observations and eq (2). The straight lines in the figure represent eq (2) using the parameters in table 5 .

TABLE 5. Regression analysis

NBS data on NBR vulcanizates

\begin{tabular}{|c|c|c|c|c|}
\hline Aging temp & $E_{\circ}$ & $k$ & $\begin{array}{l}\text { Standard } \\
\text { deviation }\end{array}$ & $\begin{array}{l}\text { Coefficient } \\
\text { of variation }\end{array}$ \\
\hline $\begin{array}{l}{ }^{\circ} \mathrm{C} \\
23 \\
34 \\
45 \\
57\end{array}$ & $\begin{array}{r}\% \\
657 \\
626 \\
608 \\
603\end{array}$ & $\begin{array}{r}6.4 \\
8.9 \\
11.4 \\
21.1\end{array}$ & $\begin{array}{r}13.5 \\
5.9 \\
3.8 \\
19.0\end{array}$ & $\begin{array}{r}\% \\
2.3 \\
1.1 \\
0.7 \\
3.9\end{array}$ \\
\hline $\begin{array}{l}70 \text { (a) } \\
70(\mathrm{~b}) \\
85 \\
100(\mathrm{a}),(\mathrm{b})^{\mathrm{a}}\end{array}$ & $\begin{array}{l}613 \\
581 \\
600 \\
647\end{array}$ & $\begin{array}{r}33.6 \\
29.8 \\
74.2 \\
180.4\end{array}$ & $\begin{array}{l}14.5 \\
34.0 \\
16.5 \\
11.7\end{array}$ & $\begin{array}{l}2.7 \\
8.3 \\
3.7 \\
2.3\end{array}$ \\
\hline
\end{tabular}

a Omitting three longest periods of aging.

\section{Interlaboratory Test}

The results of the interlaboratory test reported by Schoch and Juve [4,6] were studied. In test A of this report, there were five compounds made from different rubbers. In test $B$, there were also five compounds, three of which were made from natural rubber (NR), one from NBR, and one from styrenebutadiene rubber (SBR). Since the paper by Juve and Schoch [6] was published, data for test A have become available through Subcommittee 15 of ASTM Committee D-11, on aging at room temperature for
$8 \mathrm{yr}$. Data for the 35- and 180-min cures of the SBR compound have also become available.

Table 6 summarizes the results obtained by applying eq (2) to the ultimate elongation data of test A for aging at room temperature up to $8 \mathrm{yr}$. Except for the 90-min cure of the SBR compound, eq (2) represents the data quite well. The data for the SBR 90-min cure are very erratic and not consistent with other aging data for this vulcanizate.

TABLE 6. Regression analysis

Test $\mathrm{A}^{\text {a }}$-aging data at $25^{\circ} \mathrm{C}$ (approximately)

\begin{tabular}{|c|c|c|c|c|c|c|}
\hline Rubber & \multicolumn{2}{|c|}{ Cure } & $E_{\mathrm{o}}$ & $k$ & Standard & Coefficient \\
\hline $\mathrm{SBR}_{-. .}$ & $\begin{array}{c}\text { Min } \\
60 \\
90\end{array}$ & $\begin{array}{c}{ }^{\circ} C \\
135 \\
135\end{array}$ & $\begin{array}{c}\% \\
601 \\
553\end{array}$ & $\begin{array}{l}4.5 \\
4.9\end{array}$ & $\begin{array}{l}16 \\
44\end{array}$ & $\begin{array}{c}\% \\
3.4 \\
10.9\end{array}$ \\
\hline $\mathrm{NR}_{\ldots}$ & $\begin{array}{l}45 \\
90\end{array}$ & $\begin{array}{l}135 \\
135\end{array}$ & $\begin{array}{l}669 \\
614\end{array}$ & $\begin{array}{l}5.0 \\
5.9\end{array}$ & $\begin{array}{l}16 \\
13\end{array}$ & $\begin{array}{l}3.1 \\
3.0\end{array}$ \\
\hline $\mathrm{CR}_{\ldots}$ & $\begin{array}{l}45 \\
90\end{array}$ & $\begin{array}{l}143 \\
143\end{array}$ & $\begin{array}{l}528 \\
499\end{array}$ & $\begin{array}{l}2.8 \\
2.9\end{array}$ & $\begin{array}{r}15 \\
7\end{array}$ & $\begin{array}{l}3.4 \\
1.8\end{array}$ \\
\hline NBR_... & $\begin{array}{l}45 \\
90\end{array}$ & $\begin{array}{l}135 \\
135\end{array}$ & $\begin{array}{l}517 \\
485\end{array}$ & $\begin{array}{l}2.5 \\
2.2\end{array}$ & $\begin{array}{r}22 \\
6\end{array}$ & $\begin{array}{l}4.9 \\
1.5\end{array}$ \\
\hline IIR & $\begin{array}{l}20 \\
30\end{array}$ & $\begin{array}{l}149 \\
149\end{array}$ & $\begin{array}{l}530 \\
465\end{array}$ & $\begin{array}{l}0.4 \\
1.4\end{array}$ & $\begin{array}{l}19 \\
15\end{array}$ & $\begin{array}{l}3.6 \\
3.6\end{array}$ \\
\hline
\end{tabular}

a See references [4] and [6].

Examination of the values of $k$ in table 6 for different cures of the same compound indicates that the change in elongation during aging is not dependent on the cure except for butyl rubber (IIR). The $k$ values for the 35- and 180-min cures of the SBR

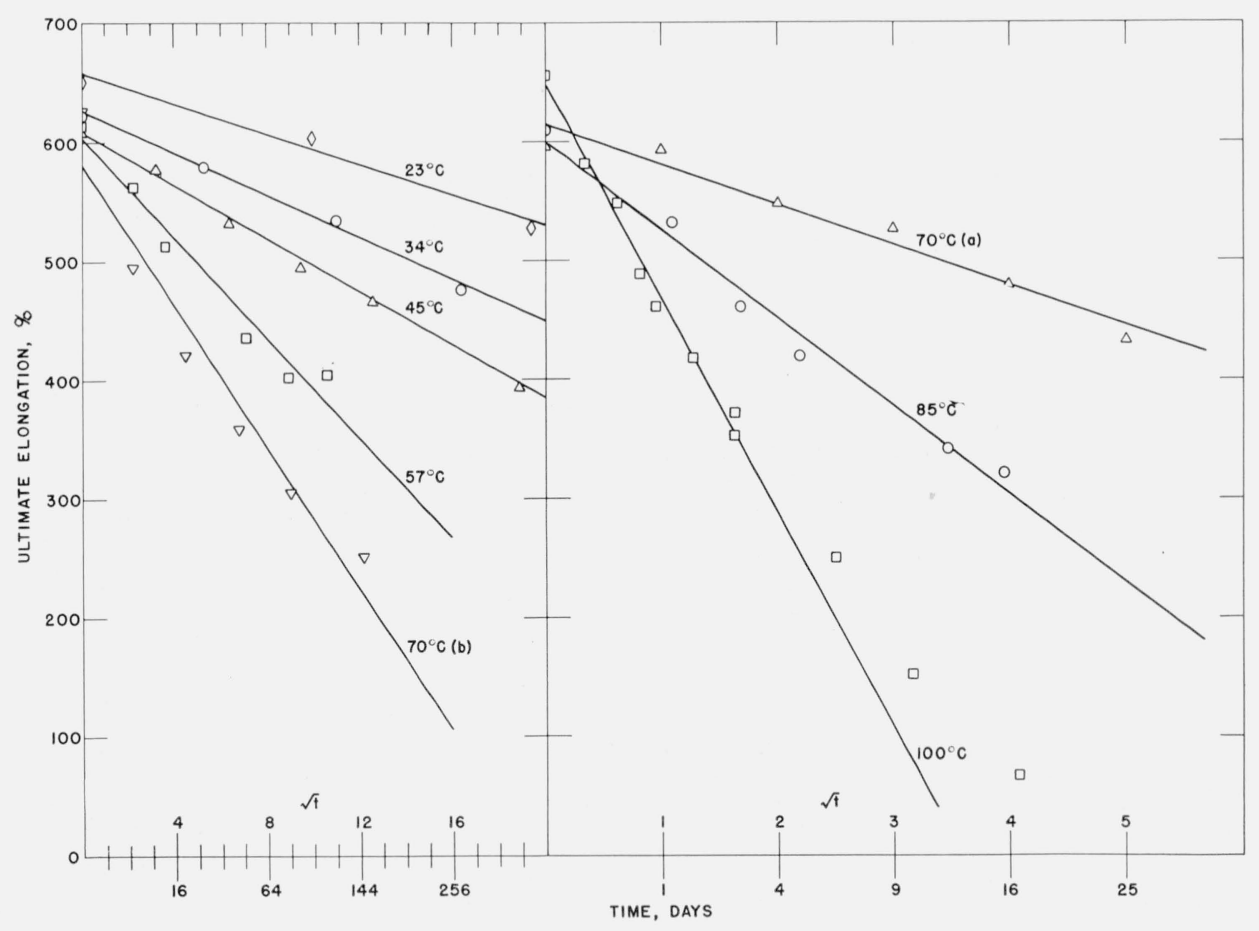

FIgURE 1. Effect of aging at various temperatures on ultimate elongation of rubber vulcanizates. The straight lines represent the least square linear regression for each temperature. The last three points at $100^{\circ} \mathrm{C}$ are not included in the regression. 
compound are about the same as those in table 6 for the 60- and 90-min cures. This independence of $k$ is also observed for all four cures at aging temperatures of $70^{\circ}$ and $100^{\circ} \mathrm{C}$. At $121^{\circ} \mathrm{C}, k$ decreases with time of cure possibly as a result of concomitant vulcanization.

Table 7 gives the values of $k$ for the five compounds at the four temperatures of aging. Only the longest cure listed in table 6 is included in table 7 . The agreement between the data and eq (2) at the three elevated temperatures is, in general, comparable to that shown in table 6 for aging at room temperature. The anomaly observed for the SBR 90 -min cure at $25^{\circ} \mathrm{C}$ is no longer present at the higher temperatures. On the other hand, the data for the IIR vulcanizate are very erratic. The erratic behavior of these vulcanizates is noted by Juve and Schoch [6].

TABLE 7. Talues of $k$ for test $A^{\text {a }}$

\begin{tabular}{|c|c|c|c|c|c|c|}
\hline Rubber & \multicolumn{2}{|c|}{ Cure } & \multicolumn{4}{|c|}{$k$ for temperature of aging } \\
\hline & & & $25^{\circ} \mathrm{C}$ & $70^{\circ} \mathrm{C}$ & $100^{\circ} \mathrm{C}$ & $121^{\circ} \mathrm{C}$ \\
\hline $\begin{array}{l}\text { SBR } \\
\text { NR } \\
\text { CR } \\
\text { NBR } \\
\text { IIR }\end{array}$ & $\begin{array}{c}\min \\
90 \\
90 \\
90 \\
90 \\
30\end{array}$ & $\begin{array}{l}{ }^{\circ} C \\
135 \\
135 \\
143 \\
135 \\
149\end{array}$ & $\begin{array}{l}4.9 \\
5.9 \\
2.9 \\
2.2 \\
1.4\end{array}$ & $\begin{array}{l}36 \\
54 \\
20 \\
34 \\
32\end{array}$ & $\begin{array}{r}117 \\
179 \\
69 \\
85 \\
97\end{array}$ & $\begin{array}{l}295 \\
363 \\
162 \\
172 \\
186\end{array}$ \\
\hline
\end{tabular}

a See references [4] and [6].

Equation (2) expresses the aging data for room temperature of test B fairly well, but not those for elevated aging temperatures. Examination of table 8 shows that the aging periods at the elevated tem- peratures in test $\mathrm{B}$ are much longer than those in test A. As a consequence, the decrease in elongation is so large in test B that eq (2) no longer applies. The data for test $\mathrm{B}$ are too limited and erratic to apply the more general eq (1).

TABLE 8. Aging conditions in interlaboratory tests a

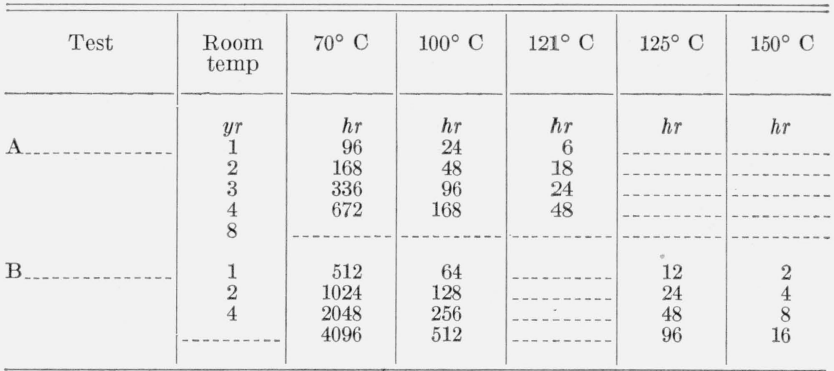

a See references [4] and [6].

\section{Effect of Temperature}

If the decrease in ultimate elongation upon aging is the result of a single chemical reaction, the parameter $k$ in eq (2) may be treated as a reaction rate constant. According to the Arrhenius equation

$$
\ln k=\frac{-\Delta H}{R T}+c,
$$

a plot of the logarithm of $k$ versus the reciprocal of the absolute temperature of aging should be linear. Figure 2 is such a plot of the data in tables 5 and 7 ,

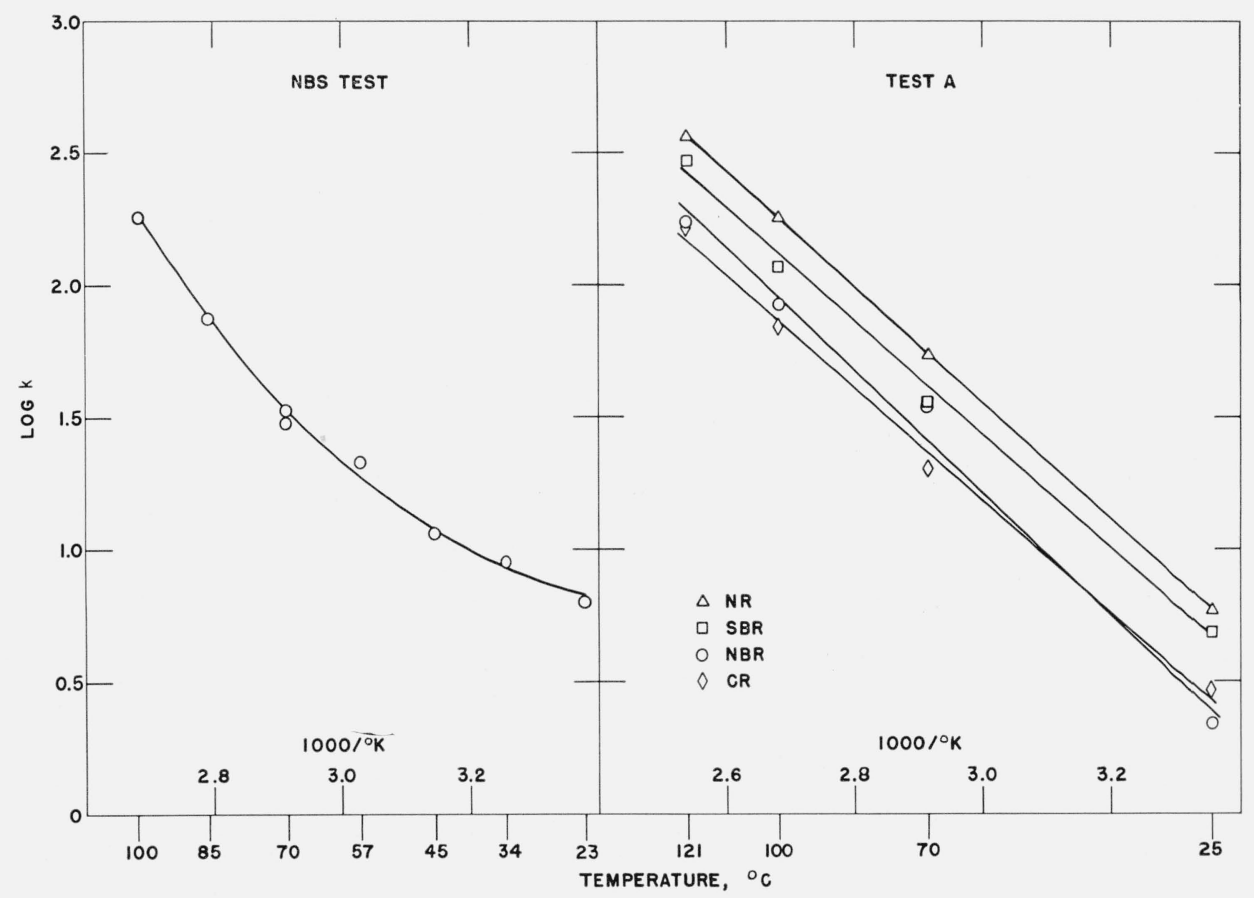

Figure 2. Effect of temperature on aging of rubber vulcanizates. The straight lines for test A represent the least square linear regressions. 
excluding the IIR compound which behaved erratically at temperatures of $70^{\circ} \mathrm{C}$ and higher. The curves for the compounds of test $\mathrm{A}$ appear to be linear. On the other hand, the curve for the NBR compound studied at NBS definitely is not linear. As the temperature increases, the rate of aging increases much faster than predicted by the Arrhenius equation. When there is curvature, prediction of shelf aging from aging tests at elevated temperature is extremely hazardous.

The slopes in figure 2 are related to the energies of activation. The values calculated for the rubber compounds of test A are: NR 20,500 cal/mole, SBR $19,600 \mathrm{cal} / \mathrm{mole}, \mathrm{CR} 19,400 \mathrm{cal} / \mathrm{mole}$, and NBR $22,100 \mathrm{cal} / \mathrm{mole}$. These values are in reasonable agreement with those reported by Juve and Schoch [6] for the 90-min cures, calculated from equal changes in ultimate elongation.

\section{Conclusions}

Ultimate elongation (strain at failure) can be used to assess the aging of all rubber vulcanizates. For this purpose, it appears that eq (2) can be used to express the early part of the aging process, corresponding to a period of aging at room temperature of 10 or more years. Prediction of shelf aging from tests at two or more elevated temperatures is only possible if the relationship between aging and temperature is known. For some rubber compounds the Arrhenius equation appears to hold. In these instances, it provides an effective means for esitmating shelf aging.

This study was supported in part by the Bureau of Aeronautics, Department of the Navy, and was presented at the International Rubber Conference, Washington, D.C., Nov. 8 to 13, 1959.

\section{References}

[1] Symposium on the physical and chemical breakdown of rubbers, Birmingham, England, Trans. Inst. Rubber Ind. 21, 49-138, 151-157 (1945).

[2] Symposium on aging of rubbers, Chicago, Ill., ASTM STP No. 89 (1949).

[3] J. M. Buist, Ageing and weathering of rubber, I.R.I. Monograph, W. Heffer \& Sons Ltd., Cambridge, England (1956)

[4] M. G. Schoch, Jr. and A. E. Juve, Effect of temperature on air aging of rubber vulcanizates, Symposium on aging of rubbers, ASTM STP No. 89, 59 (1949).

[5] 1958 Book of ASTM Standards, pt. 9, Am. Soc. Testing Materials, Philadelphia, Pa.

[6] A. E. Juve and M. G. Schoch, Jr., The effect of temperature on the air aging of rubber vulcanizates, ASTM Bull. No. 195, 54 (1954).

Washington, D.C.

(Paper 63C2-17) 